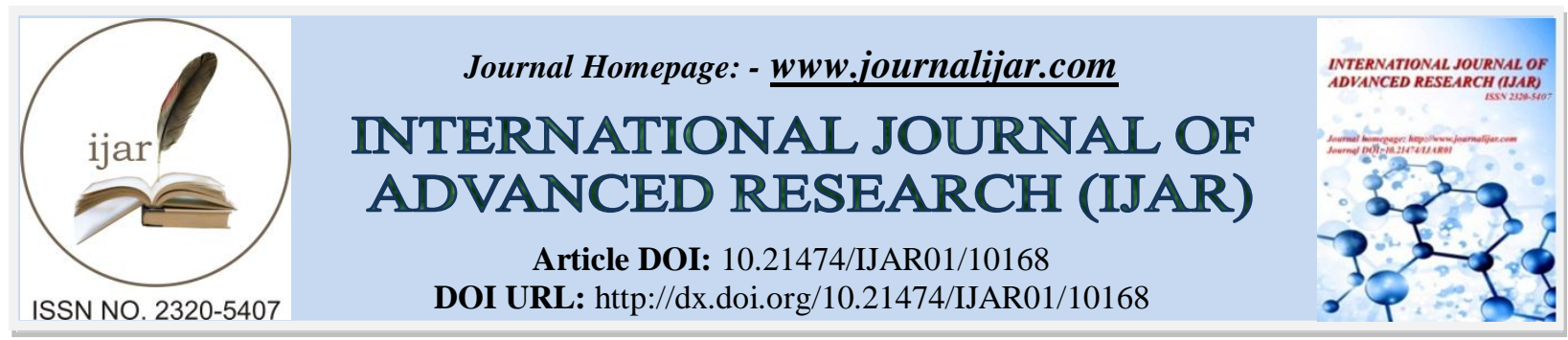

RESEARCH ARTICLE

\title{
EFFECT OF PHYSICO-CHEMICAL ATTRIBUTES ON THE ABUNDANCE AND SPATIAL DISTRIBUTION OF FISH SPECIES IN LAKE TANGANYIKA, BURUNDIAN COAST.
}

\section{Lambert Niyoyitungiye ${ }^{1,2}$, Anirudha Giri ${ }^{1}$ and Bhanu Prakash Mishra ${ }^{3}$.}

1. Department of Life Science and Bioinformatics, Assam University, Silchar-788011, Assam State, India.

2. Department of Environmental Science and Technology, Faculty of Agronomy and Bio-Engineering, University of Burundi, Bujumbura, Po Box.2940, Burundi.

3. Department of Environmental Science, Mizoram University, Aizawl-796004, Mizoram State, India.

\section{Manuscript Info}

\section{Manuscript History}

Received: 03 October 2019

Final Accepted: 05 November 2019

Published: December 2019

Key words:-

Fish Abundance, Physico-Chemical Attributes, Spatial Distribution, Lake Tanganyika.

\begin{abstract}
The water of Lake Tanganyika is subject to changes in physical and chemical characteristics and resulting in the deterioration of water quality to a great pace. The current study was carried out to assess the physical and chemical characteristics of water at 4sampling stations of Lake Tanganyika and intended, firstly to make an inventory and a taxonomic characterization of all fish species found in the study sites, secondly to determine the pollution status of the selected sites and the impact of physico-chemical parameters on the abundance and spatial distribution of fish species in the Lake.

The results obtained regarding the taxonomy and abundance of fish species showed that a total of 75 fish species belonging to 12 families and 7 orders existed in the 4 selected sampling stations. Besides, it has been proved that Kajaga and Nyamugari stations were heavily polluted while Rumonge and Mvugo Stations were moderately polluted. Karl Pearson's correlation coefficient calculated between physico-chemical parameters values and the number of fish species showed strong positive and negative correlation which revealed that physico-chemical parameters have respectively a high influence on the increase and on the decrease of fish species amount in the study environment and at the same time, one way ANOVA and Tukey's Honestly Significant Difference test (Tukey's HSD) showed that the influence of the sampling stations on the abundance of fish species is highly significant $(\mathrm{P}=0.007)$.

Copy Right, IJAR, 2019,. All rights reserved.
\end{abstract}

\section{Introduction:-}

The healthy aquatic ecosystem is depending on the physico-chemical and biological characteristics (Venkatesharaju et al., 2010). Freshwater resources across the world are facing serious pollution problems due to various anthropogenic activities, mainly the indiscriminate disposal of waste effluents, population growth, the rise of industrialization and the increasing use of phytosanitary products (fertilizers and pesticides) in agriculture. These activities, particularly in developing countries, have caused the degradation of aquatic environments which change the physiology and ecology of aquatic biota (Khanna and Ishaq, 2013), threaten the balance of aquatic ecosystems, animal and plant communities (Noukeu et al., 2016). Consequently, an intensification of eutrophication resulting in

Corresponding Author:- Lambert Niyoyitungiye.

Address:- Department of Life Science and Bioinformatics, Assam University, Silchar-788011, Assam State, India. 
undesirable effects such as a decrease in biodiversity and an increase in tolerant species to pollution is observed (Roxane and Reinhard, 2015).

Nevertheless, freshwater fish are one of the most threatened taxonomic groups (Darwall and Vie, 2005) because of their high sensitivity to the quantitative and qualitative alteration of aquatic habits (Laffaille et al., 2005; Kang et al., 2009; Sarkar et al., 2008). Due to the habitat destruction and defragmentation (Cuizhang et al.,2003), water abstraction, industries and private use (Szollosi-Nagy,2004; Ricciardi and Rasmussen,1999; Gibbs, 2000; Dawson et al.,2003), increasing surface water pollution (Lima-Junior et al.,2006), global climate change impacts (Leveque et al.,2005;Mas-Marti et al.,2010) and overfishing, it has been realized that many fish species have become highly endangered, fish richness and diversity are rapidly declining and many species have become extinct (Pompeu and Alves,2003; Pompeu and Alves,2005; Shukla and Singh,2013; Mohite and Samant,2013; Joshi,2014). As a consequence, the Freshwater fish are often used as bioindicators for the assessment of the water quality, river network connectivity or flow regime (Chovance et al., 2003). The water quality assessment is therefore essential to identify magnitude and source of any pollution load and provides significant information about the available resources for supporting life in a considered ecosystem. Any change in the water quality has direct influence on biotic communities where different species of flora and fauna exhibit great variations in their responses to the environment (Watson and John, 2003).

The present study was conducted on Lake Tanganyika which is one of the largest lakes of Africa and second biggest lake considering the area after Lake Victoria .At the world level, Lake Tanganyika is the longest freshwater lake and holds second position in terms of volume and depth after Lake Baikal (Wetzel, 1983). It is surrounded by four countries (Burundi, Democratic Republic of Congo, Tanzania and Zambia) sharing its entire perimeter unequally. However, the surface waters of Lake Tanganyika are highly polluted by different harmful contaminants from human activities in large cities and are subject to frequent fluctuations in their physico-chemical characteristics and to desiccation (Wetzel, 2001) due to sudden changes in weather Conditions. That is why the current study was undertaken to assess the present status of fish community structure and the impact of physico-chemical characteristics of water on the abundance, diversity and spatial distribution of fish species in four sampling stations.

\section{Materials and Methods:-}

\section{Study area:-}

As the lake has a long perimeter $(1838 \mathrm{~km})$ shared between four countries (Burundi, Tanzania, Democratic Republic of Congo and Zambia), the data collection on fish species caught in the lake, and water sample for laboratory analyses was carried out at 4 study sites (Kajaga, Nyamugari, Rumonge and Mvugo) belonging to the Burundian Littoral and the distance separating the selected study sites was at least $20 \mathrm{~km}$. The figure 1 and table1 below show the geographical location of the study areas:

Figure 1:- Map of the study area showing sampling sites.

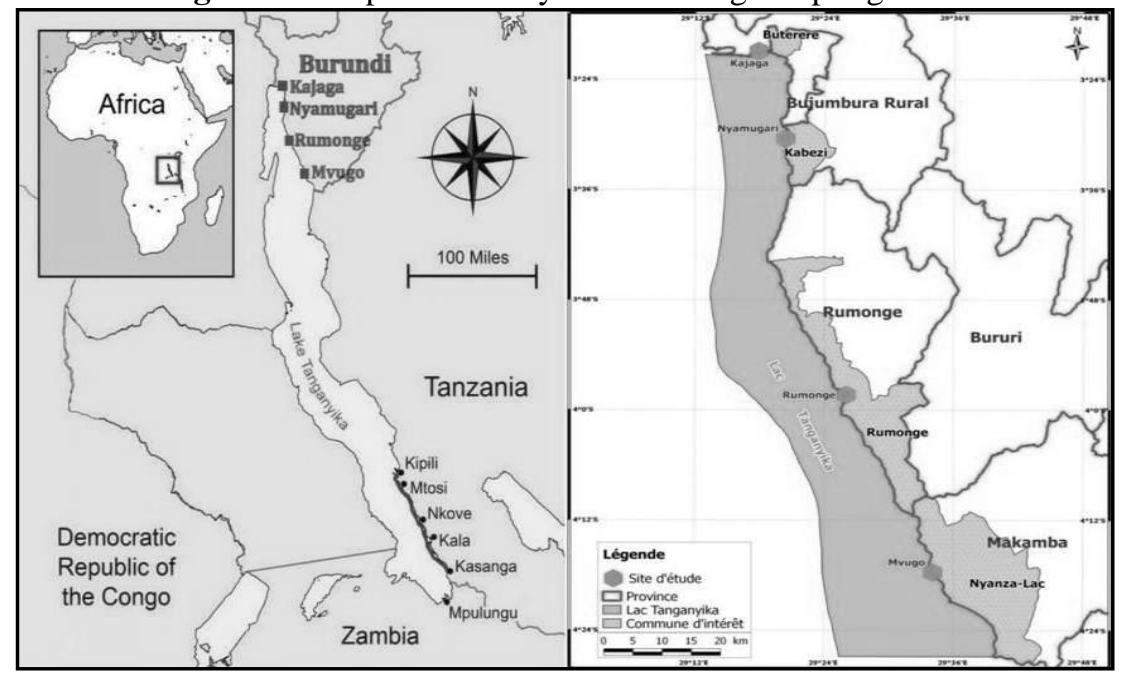


Table 1:- Geographical location of the study sites.

\begin{tabular}{|l|l|l|l|l|l|}
\hline \multirow{2}{*}{ Sampling stations } & \multicolumn{5}{|c|}{ Geographical Location } \\
\cline { 2 - 6 } & Province & Commune & Longitude-East & Latitude-South & Altitude \\
\hline Kajaga & Bujumbura Rural & Buterere & $029^{\circ} 17^{\prime} 56^{\prime}{ }^{\prime}$ & $03^{\circ} 20^{\prime} 55^{\prime}$ & $783 \mathrm{~m}$ \\
\hline Nyamugari & Bujumbura Rural & Kabezi & $029^{\circ} 20^{\prime} 24^{\prime \prime}$ & $03^{\circ} 30^{\prime} 27^{\prime}$, & $776 \mathrm{~m}$ \\
\hline Rumonge & Rumonge & Rumonge & $029^{\circ} 26^{\prime} 03^{\prime \prime}$ & $03^{\circ} 58^{\prime} 23^{\prime \prime}$ & $767 \mathrm{~m}$ \\
\hline Mvugo & Makamba & Nyanza-Lac & $029^{\circ} 34^{\prime} 06^{\prime}$, & $04^{\circ} 17^{\prime} 42^{\prime}$, & $810 \mathrm{~m}$ \\
\hline
\end{tabular}

\section{Sampling and field data collection:-}

Fish species sampling and taxonomic identification:-

The sampling of fish species was carried out twice per month during three months (January, February and March both for 2017 and 2018). Fish samples were collected from various sampling sites with the help of local fishermen using different types of nets namely gill nets, cast nets and drag nets and much other valuable information were obtained by physical verification and interview with the people residing nearby the selected stations (Figure 2).

All the collected fish specimens were identified at the point of capture according to the Taxonomic identification keys of Paugy et al. (2003), Dutta Munshi and Shrivastava (1988); Talwar and Jhingran (1991), Vishwanath (2002) and Jayaram(1999), Allen (1991), Watson (1992), Allen et al. (2000) and Marquet et al. (2003). The identification of the scientific names corresponding to the vernacular names cited by the fishermen was made using the Lexicon of Kirundi names established by Ntakimazi, Nzigidahera and Fofo (2007). The taxonomic list of the collected species followed the organization proposed by Nelson (1994), as well as the modifications suggested by Fink \& Fink (1981), Lauder \& Liem (1983).

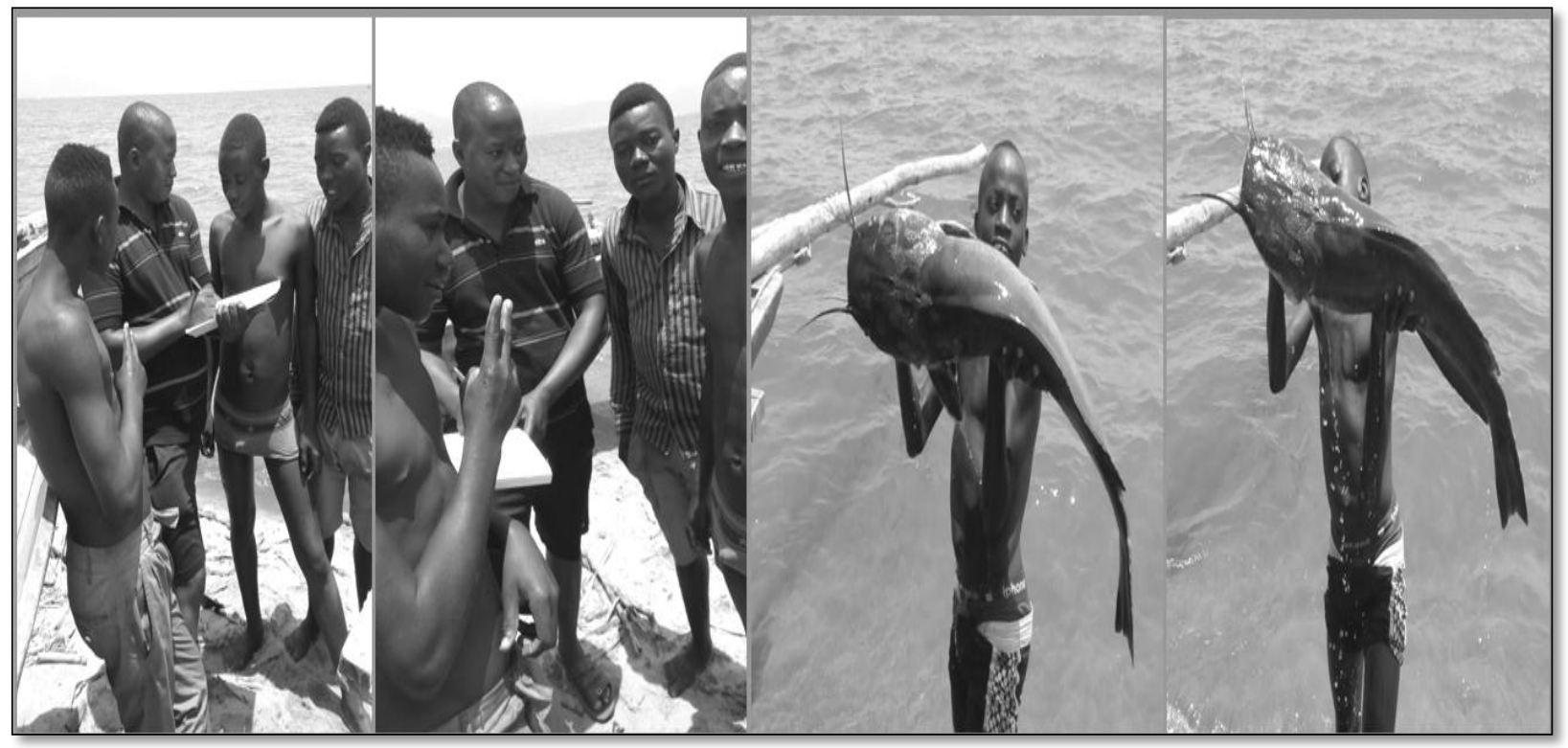

Figure 2:- Group interview with local fishermen at Kajaga station.

The comparative study of the spatial variations of the diversity of fish population for the studied stations was carried out using two commonly used indices: Jaccard (1908) and Sorensen (1948) coefficients which show the similarity or dissimilarity between fish species recorded in the sampling stations on the basis of the presence-absence of species. Jaccard's Index: $S_{j}=\frac{C}{A+B+C}$

This index can be modified to a coefficient of dissimilarity by taking its inverse:

Jaccard's dissimilarity coefficient $=1-S_{j}=\frac{A+B}{A+B+C}$

Sorensen's Index: $S_{s}=\frac{2 C}{2 C+A+B}$ 
This measure is very similar to Jaccard's measure and can also be modified to a coefficient of dissimilarity by taking its inverse:

Sorensen's dissimilarity coefficient $=1-S_{s}=\frac{A+B}{2 C+A+B}$,

Where:

$\mathrm{S}_{\mathrm{j}}=$ Jaccard's similarity coefficient

$\mathrm{S}_{\mathrm{S}}=$ Sorensen's similarity coefficient

$\mathrm{C}=$ Number of species common or shared between two sampling station

$A=$ Number of species present only in the first sampling station

$\mathrm{B}=$ Number of species present only in the second sampling station

\section{Water samples for physico-chemical analyses:-}

During the present investigation, field data collection has lasted 6months, at 3 months per year (January, February and March both for 2017 and 2018) and the various outings were always conducted in the morning time. The water samples for Physical and chemical analyses were collected from different Study sites with plastic containers in the morning time. The containers were thoroughly washed and sterilized to avoid extraneous contamination. All samples were adequately labeled and transported immediately to the laboratory for analyzing of different parameters. Some physical and chemical parameters such as Temperature, Electrical Conductivity, $\mathrm{pH}$ and Dissolved Oxygen have been measured in-situ (at the time and on the sampling sites of sample collection) using Electrometric method (conductivity meter and $\mathrm{pH}$-meter) while the remaining parameters were determined in the Laboratory using the standard methods (APHA, 2005; Trivedy and Goel, 1986). The methods adopted for water quality analysis and the used instruments are listed in the table 2 below:

Table 2:- Analytical methods adopted to determine quality of lake water.

\begin{tabular}{|l|l|l|}
\hline Parameters & Methods & Equipments / Instruments \\
\hline Turbidity (NTU) & Turbidity tube method & $\begin{array}{l}\text { Jackson's Candle Turbiditimeter, } \\
\text { Turbidity tube or Nephelometer }\end{array}$ \\
\hline Temperature & Temperature sensitive probe & Mercury thermometer \\
\hline Total Dissolved Solids & $\begin{array}{l}\text { Evaporation method, Electrometric, } \\
\text { and Gravimetric method }\end{array}$ & Conductivity meter \\
\hline Transparency & Secchi DiskVisibilityMethod & Secchi disk \\
\hline PH, Electrical Conductivity & Electrometric method & pH-meter, Conductivity meter \\
\hline Dissolved Oxygen & $\begin{array}{l}\text { Alsterberg Azide Modification } \\
\text { of the Winkler's Method. }\end{array}$ & Dissolved Oxygen meter \\
\hline $\begin{array}{l}\text { Total hardness, Calcium } \\
\text { and Magnesium }\end{array}$ & EDTA Titration method & - \\
\hline Chlorides & $\begin{array}{l}\text { Titration by AgNO } \\
\text { Mohr's method. }\end{array}$ & - \\
\hline BOD & $\begin{array}{l}5 \text { days incubation at } 20^{\circ} \mathrm{C} \text { followed } \\
\text { by titration }\end{array}$ & BOD Incubator \\
\hline Total alkalinity & Titration by $\mathrm{H}_{2} \mathrm{SO}_{4}$ & - \\
\hline COD & Digestion followed by titration & COD Digestor \\
\hline Total Carbon, Total Nitrogen & Titrimetric method & - \\
\hline Total.Phosphorus & $\begin{array}{l}\text { Digestion by ascorbic acid } \\
\text { followed Spectrophotometric Mehod }\end{array}$ & Spectrophotometer \\
\hline
\end{tabular}

Data analyses:-

All the Statistical analyses were carried out using the software SPSS.20.0 and those analyses include: A descriptive analysis to describe the minimum, maximum, average and standard deviations corresponding to the Physicochemical parameters values; Pearson's correlation analysis to assess pair wise associations between variables (Physico-chemical parameters values and Fish species amount) and the strength of their relations; One-way analysis of variance (ANOVA-1) to show the effect of physico-chemical parameters on the variation of fish species number in sampling stations; Tukey's Honestly Significant Difference test (Tukey's HSD) which is the one way ANOVA post hoc non parametric test to make the comparison among the means of fish species number from different samplings stations. 


\section{Results and Discussion:-}

Physico-chemical characteristics:-

Monitoring physico-chemical parameters is very important for studying the influence of these parameters on the distribution of various components of biodiversity in headwater stream (Sharma et al., 2007). Water quality is influenced by geological, hydrological, climatic and anthropogenic factors (Boon et al., 1992; Bartram and Balance, 1996). In the present study, the physical and chemical parameters evaluated were Turbidity (Tur), Temperature (Te), Potential of Hydrogen (PH), Transparency (Tr),Total Alkalinity (TA), Electrical Conductivity(EC), Total Dissolved Solids (TDS), Chlorides ( $\left.\mathrm{Cl}^{-}\right)$, Total Hardness (TH), Calcium (Ca2+), Magnesium (Mg2+), Iron (Fe), Total Carbon (TC), Total Nitrogen (TN), Total Phosphorus (TP), Dissolved Oxygen (DO), Percent of Oxygen Saturation, Chemical Oxygen Demand (COD) and Biochemical Oxygen Demand (BOD). The annual average data per Sampling stations and the descriptive statistics are presented in the table3.

Table 3:- Annual average values for water quality characteristics and descriptive statistics.

\begin{tabular}{|c|c|c|c|c|c|c|c|c|}
\hline \multirow[t]{2}{*}{ Parameters } & \multicolumn{4}{|c|}{ Mean per study site } & \multicolumn{4}{|c|}{ Descriptive Statistical data } \\
\hline & Kajaga & Nyamugari & Rumonge & Mvugo & Min & Max & G M & SD \\
\hline Tur (NTU) & 0.51 & 10.11 & 1.55 & 1.37 & 0.51 & 10.11 & 3.38 & 4.17 \\
\hline $\mathrm{Te}\left({ }^{\circ} \mathrm{C}\right)$ & 27.60 & 27.95 & 28.95 & 28.60 & 27.60 & 28.95 & 28.28 & 0.57 \\
\hline $\operatorname{Tr}(\mathrm{cm})$ & 200.00 & 120.00 & 168.00 & 161.50 & 120.00 & 200.00 & 162.38 & 30.44 \\
\hline TDS (mg.L $\left.\mathbf{L}^{-1}\right)$ & 448.57 & 449.24 & 444.88 & 445.89 & 444.88 & 449.24 & 447.14 & 1.93 \\
\hline pH & 8.85 & 8.88 & 8.71 & 8.60 & 8.60 & 8.88 & 8.76 & 0.12 \\
\hline TA (mg.L L $\left.^{-1}\right)$ & 325.05 & 345.80 & 337.30 & 349.60 & 325.05 & 349.58 & 339.44 & 10.08 \\
\hline $\mathrm{EC}(\mu \mathrm{s} / \mathrm{cm})$ & 669.50 & 670.50 & 664.00 & 665.50 & 664.00 & 670.50 & 667.38 & 2.89 \\
\hline $\mathrm{Cl}^{-}\left(\mathbf{m g} \cdot .^{-1}\right)$ & 46.58 & 32.27 & 38.27 & 36.15 & 32.27 & 46.58 & 38.31 & 5.59 \\
\hline TH $\left(\right.$ mg. L $\left.^{-1}\right)$ & 218.20 & 193.10 & 207.65 & 166.95 & 166.95 & 218.20 & 196.48 & 20.56 \\
\hline $\mathrm{Ca}^{2+}\left(\mathrm{mg}^{2} \mathrm{~L}^{-1}\right)$ & 56.73 & 34.08 & 42.59 & 37.81 & 34.08 & 56.73 & 42.80 & 9.18 \\
\hline $\operatorname{Mg}^{2+}\left(\mathrm{mg} \mathrm{L}^{-1}\right)$ & 18.57 & 26.22 & 24.59 & 17.60 & 17.60 & 26.22 & 21.74 & 3.98 \\
\hline $\mathrm{Fe}\left(\mathrm{mg} \cdot \mathrm{L}^{-1}\right)$ & 0.026 & 0.019 & 0.166 & 0.085 & 0.019 & 0.166 & 0.074 & 0.063 \\
\hline TC $\left(\mathrm{mg}^{\prime} \mathrm{L}^{-1}\right)$ & 78.25 & 80.68 & 73.52 & 75.50 & 73.52 & 80.68 & 76.99 & 2.90 \\
\hline TN $\left(\right.$ mg. $\left.L^{-1}\right)$ & 0.33 & 0.15 & 0.13 & 0.21 & 0.13 & 0.33 & 0.21 & 0.08 \\
\hline TP (mg. L $\left.^{-1}\right)$ & 1.64 & 1.62 & 0.86 & 0.74 & 0.74 & 1.64 & 1.21 & 0.45 \\
\hline DO $\left(m g . L^{-1}\right)$ & 7.61 & 7.43 & 7.26 & 7.20 & 7.20 & 7.61 & 7.38 & 0.17 \\
\hline DO (\%) & 96.60 & 95.13 & 94.54 & 93.04 & 93.04 & 96.60 & 94.83 & 1.36 \\
\hline COD $\left(\mathrm{mg} \cdot \mathrm{L}^{-1}\right)$ & 67.50 & 28.00 & 21.50 & 20.00 & 20.00 & 67.50 & 34.25 & 20.77 \\
\hline BOD (mg.L $\left.\mathrm{L}^{-1}\right)$ & 14.00 & 10.30 & 7.50 & 6.25 & 6.25 & 14.00 & 9.51 & 3.18 \\
\hline
\end{tabular}

Note:- GM: general Mean, Min: Minimum, Max: Maximum, SD: Standard Deviation.

Interaction between physico-chemical parameters, study stations and Fish species:

Taxonomic diversity of fish species found in study stations:-

The usual sketch in the organisms classification is as follows:

Kingdom $\longrightarrow$ Phylum $\longrightarrow$ Class $\longrightarrow$ Order $\longrightarrow$ Family $\longrightarrow$ Genus $\longrightarrow$ Species.

During the investigation, 75 species belonging to 12 families and 7 Orders were recorded from all sampling sites and all these species belong to the animal kingdom, Phylum of chordata, class of Actinopterygii. The relative diversity index of families (Figure 3A) has indicated that Cichlidae is the most dominant family compared to others with 45 species $(60 \%)$. The Claroteidae holds second position with 7 species (10\%), the Latidae occupies the third position with 6 species $(8 \%)$, the family Clupeidae contains 4 species $(5 \%)$ and holds the fourth place, the family Alestidae with 3 species (4\%) holds the fifth position. The families Clariidae, Poeciliidae and Mochokidae occupy the sixth position and comprised of 2 species (3\%) each. The families Mastacembelidae, Cyprinidae, Bagridae and Malapteruridae occupy the last position with only one specie $(1 \%)$ each.

Regarding the fish species distribution per orders (figure 3B), it has been realized that the order Perciformes is the most dominant with 51species (68\%), followed by Siluriformes order with 13 species (17\%), then Clupeiformes order with 4 species $(6 \%)$. Characiformes order with 3 species $(4 \%)$ and Cyprinodontiformes order with 2 species (3\%) occupy respectively the fourth and the fifth positions while Synbranchiformes and Cypriniformes order hold last position with one specie $(1 \%)$ each. 
The results regarding the species richness of the sampling sites (figure 3C) showed that Rumonge site holds first position with 48 and 44 species respectively in 2017 and 2018 with an average of 46 species, Mvugo site holds the second position with a constant number of 42 species for both years, Kajaga site in third position with 37 and 33 species in 2017 and 2018 respectively with an average of 35 species while Nyamugari site seemed to be very poor with 26 and 30 species in 2017 and 2018 respectively with an average of 28 species. Indeed, after one year, the extinction of 4 fish species was observed at Rumonge and Kajaga stations while 4 species were appeared at Nyamugari Stations. The scientific names (Binary names) of all fish species with their corresponding families and orders are listed in the table 4.
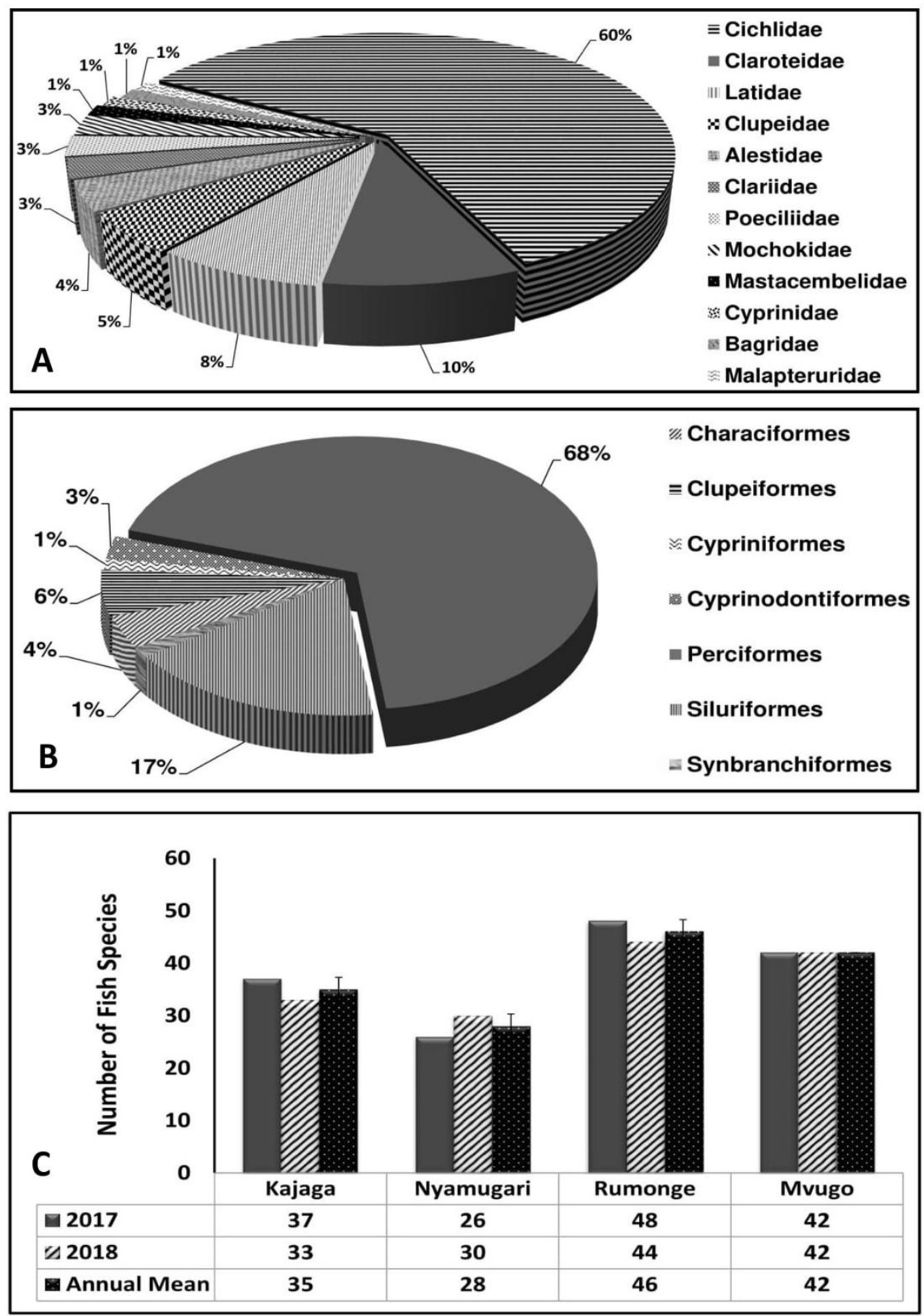

Figure 3:- Allotment of fish species per families(A) and per orders (B) and Number of fish species per sampling stations $(\mathrm{C})$. 
Table 4:- Fish species diversity at selected sampling stations.

\begin{tabular}{|c|c|c|c|c|c|c|c|c|}
\hline \multirow[t]{2}{*}{ Order $\longrightarrow$ Family $\longrightarrow$ Species } & \multicolumn{2}{|c|}{ Rumonge } & \multicolumn{2}{|c|}{ Mvugo } & \multicolumn{2}{|c|}{ Kajaga } & \multicolumn{2}{|c|}{ Nyamugari } \\
\hline & 2017 & 2018 & 2017 & 2018 & 2017 & 2018 & 2017 & 2018 \\
\hline \multicolumn{9}{|l|}{$\begin{array}{l}\text { 1. Order: Characiformes } \\
\text { 1.1. Family: Alestidae }\end{array}$} \\
\hline 1. Alestes macrophtalmus & $\mathrm{X}$ & $\mathrm{X}$ & $\mathrm{X}$ & $\mathrm{X}$ & & & & \\
\hline 2. Hydrocynus forskahili & & & & & $\mathrm{X}$ & $\mathrm{X}$ & & \\
\hline 3. Hydrocynus goliath & $\mathrm{X}$ & $\mathrm{X}$ & & & $\mathrm{X}$ & $\mathrm{X}$ & & \\
\hline \multicolumn{9}{|l|}{$\begin{array}{l}\text { 2. Order: Perciformes } \\
\text { 2. 1. Family: Cichlidae }\end{array}$} \\
\hline 4. Neolamprologus pleuromaculatus & & & $\mathrm{X}$ & $\mathrm{X}$ & & & & \\
\hline 5. Aulonocranus dewindti & $\mathrm{X}$ & $\mathrm{X}$ & & & & & $\mathrm{X}$ & $\mathrm{X}$ \\
\hline 6. Bathybates fasciatus & $\mathrm{X}$ & $\mathrm{X}$ & $\mathrm{X}$ & $\mathrm{X}$ & $\mathrm{X}$ & $\mathrm{X}$ & $\mathrm{X}$ & $\mathrm{X}$ \\
\hline 7. Bathybates leo & $\mathrm{X}$ & $\mathrm{X}$ & & & & & $\mathrm{X}$ & $\mathrm{X}$ \\
\hline 8. Bathybates minor & $\mathrm{X}$ & $\mathrm{X}$ & & & $\mathrm{X}$ & $\mathrm{X}$ & $\mathrm{X}$ & $\mathrm{X}$ \\
\hline 9. Benthochromis tricoti & $\mathrm{X}$ & $\mathrm{X}$ & & & & & & \\
\hline 10. Boulengerochromis micolepis & $\mathrm{X}$ & $\mathrm{X}$ & $\mathrm{X}$ & $\mathrm{X}$ & $\mathrm{X}$ & $\mathrm{X}$ & $\mathrm{X}$ & $\mathrm{X}$ \\
\hline 11. Callochromis macrops macrops & $\mathrm{X}$ & & & & & & $\mathrm{X}$ & $\mathrm{X}$ \\
\hline 12. Callochromis pleurospilus & & & & & & & $\mathrm{X}$ & $\mathrm{X}$ \\
\hline 13. Ctenochromis horei & & & $\mathrm{X}$ & $\mathrm{X}$ & & & $\mathrm{X}$ & $\mathrm{X}$ \\
\hline 14. Cyathopharynx fulcifer & & & $\mathrm{X}$ & $\mathrm{X}$ & & & & \\
\hline 15. Cyphotilapia frontosa & $\mathrm{X}$ & $\mathrm{X}$ & & & & & & \\
\hline 16. Gnathochromis pfefferi & $\mathrm{X}$ & $\mathrm{X}$ & $\mathrm{X}$ & $\mathrm{X}$ & $\mathrm{X}$ & $\mathrm{X}$ & & \\
\hline 17. Haplochromis burtoni & $\mathrm{X}$ & $\mathrm{X}$ & & & $\mathrm{X}$ & $\mathrm{X}$ & $\mathrm{X}$ & $\mathrm{X}$ \\
\hline 18. Haplotaxodon microlepis & & & & & $\mathrm{X}$ & $\mathrm{X}$ & & \\
\hline 19. Hemibates stenosoma & $\mathrm{X}$ & $\mathrm{X}$ & $\mathrm{X}$ & $\mathrm{X}$ & $\mathrm{X}$ & $\mathrm{X}$ & $\mathrm{X}$ & $\mathrm{X}$ \\
\hline 20. Lamprologus callipterus & $\mathrm{X}$ & $\mathrm{X}$ & & & & & & \\
\hline 21. Lamprologus lemairii & $\mathrm{X}$ & $\mathrm{X}$ & & & & & & \\
\hline 22. Lepidiolamprologus attenuatus & $\mathrm{X}$ & $\mathrm{X}$ & & & & & & \\
\hline 23. Lepidiolamprologus cunningtoni & $\mathrm{X}$ & $\mathrm{X}$ & $\mathrm{X}$ & $\mathrm{X}$ & & & $\mathrm{X}$ & $\mathrm{X}$ \\
\hline 24. Lepidiolamprologus elongarus & & & & & & & $\mathrm{X}$ & $\mathrm{X}$ \\
\hline 25. Limnochromis auritus & $\mathrm{X}$ & $\mathrm{X}$ & & & & & $\mathrm{X}$ & $\mathrm{X}$ \\
\hline 26. Limnotilapia dardennei & $\mathrm{X}$ & $\mathrm{X}$ & $\mathrm{X}$ & $\mathrm{X}$ & $\mathrm{X}$ & $\mathrm{X}$ & $\mathrm{X}$ & $\mathrm{X}$ \\
\hline 27. Lobochilotes labiatus & $\mathrm{X}$ & & $\mathrm{X}$ & $\mathrm{X}$ & & & & \\
\hline 28. Neolamprologus brevis & $\mathrm{X}$ & $\mathrm{X}$ & & & & & & $\mathrm{X}$ \\
\hline 29. Neolamprologus Calvus & $\mathrm{X}$ & $\mathrm{X}$ & $\mathrm{X}$ & $\mathrm{X}$ & $\mathrm{X}$ & $\mathrm{X}$ & & \\
\hline 30. Neolamprologus compressiceps & $\mathrm{X}$ & $\mathrm{X}$ & $\mathrm{X}$ & $\mathrm{X}$ & & & & \\
\hline 31. Neolamprologus tetracanthus & & & $\mathrm{X}$ & $\mathrm{X}$ & & & & \\
\hline 32. Opthalmotilapia ventralis & & & & & $\mathrm{X}$ & $\mathrm{X}$ & & \\
\hline 33. Oreochromis niloticus & $\mathrm{X}$ & $\mathrm{X}$ & $\mathrm{X}$ & $\mathrm{X}$ & & & $\mathrm{X}$ & $\mathrm{X}$ \\
\hline 34. Oreochromis tanganicae & $\mathrm{X}$ & $\mathrm{X}$ & $\mathrm{X}$ & $\mathrm{X}$ & $\mathrm{X}$ & $\mathrm{X}$ & & \\
\hline 35. Perissodus microlepis & $\mathrm{X}$ & $\mathrm{X}$ & $\mathrm{X}$ & $\mathrm{X}$ & & & & \\
\hline 36. Reganochromis calliurum & & & & & & & $\mathrm{X}$ & $\mathrm{X}$ \\
\hline 37. Simochromis marginatus & & & $\mathrm{X}$ & $\mathrm{X}$ & & & & \\
\hline 38. Telmatochromis temporalis & $\mathrm{X}$ & & & & & & & \\
\hline 39. Trematocara marginatum & $\mathrm{X}$ & $\mathrm{X}$ & $\mathrm{X}$ & $\mathrm{X}$ & & & & \\
\hline 40. Trematocara variabile & & & $\mathrm{X}$ & $\mathrm{X}$ & & & $\mathrm{X}$ & $\mathrm{X}$ \\
\hline 41. Triglachromis otostigma & & & & & & & $\mathrm{X}$ & $\mathrm{X}$ \\
\hline 42. Tropheus brichardi & & & $\mathrm{X}$ & $\mathrm{X}$ & & & & \\
\hline 43. Tylochromis polylepis & & & $\mathrm{X}$ & $\mathrm{X}$ & & & $\mathrm{X}$ & $\mathrm{X}$ \\
\hline 44. Xenotilapia boulengeri & $\mathrm{X}$ & $\mathrm{X}$ & $\mathrm{X}$ & $\mathrm{X}$ & & & & \\
\hline 45. Xenotilapia burtoni & $\mathrm{X}$ & $\mathrm{X}$ & & & $\mathrm{X}$ & $\mathrm{X}$ & & \\
\hline 46. Xenotilapia flavipinnis & $\mathrm{X}$ & $\mathrm{X}$ & & & & & $\mathrm{X}$ & $\mathrm{X}$ \\
\hline 47. Xenotilapia longispinis burtoni & & & & & $\mathrm{X}$ & $\mathrm{X}$ & & \\
\hline
\end{tabular}




\begin{tabular}{|c|c|c|c|c|c|c|c|c|}
\hline \multirow{2}{*}{\multicolumn{9}{|c|}{$\begin{array}{l}\text { 48. Xenotilapia sima } \\
\text { 2.2. Family: Latidae }\end{array}$}} \\
\hline & & & & & & & & \\
\hline 49. Lates angustifrons & & & & & $\mathrm{X}$ & & & \\
\hline 50. Lates mariae & $\mathrm{X}$ & $\mathrm{X}$ & $\mathrm{X}$ & $\mathrm{X}$ & $\mathrm{X}$ & $\mathrm{X}$ & $\mathrm{X}$ & $\mathrm{X}$ \\
\hline 51. Luciolates stappersii juv. & $\mathrm{X}$ & $\mathrm{X}$ & $\mathrm{X}$ & $\mathrm{X}$ & $\mathrm{X}$ & $\mathrm{X}$ & & \\
\hline 52. Lates microlepis & & & & & $\mathrm{X}$ & $\mathrm{X}$ & & \\
\hline 53. Luciolates microlepis & $\mathrm{X}$ & $\mathrm{X}$ & $\mathrm{X}$ & $\mathrm{X}$ & $\mathrm{X}$ & $\mathrm{X}$ & & $\mathrm{X}$ \\
\hline 54. Luciolates stappersi & $\mathrm{X}$ & $\mathrm{X}$ & $\mathrm{X}$ & $\mathrm{X}$ & $\mathrm{X}$ & $\mathrm{X}$ & & \\
\hline \multicolumn{9}{|l|}{$\begin{array}{l}\text { 3. Order: Siluriformes } \\
\text { 3.1. Family: Mochokidae }\end{array}$} \\
\hline 55. Synodontis lacustricolus & & & & & $\mathrm{X}$ & & & \\
\hline 56. Synodontis multipuctatus & & & $\mathrm{X}$ & $\mathrm{X}$ & & & & \\
\hline \multicolumn{9}{|l|}{ 3.2. Family: Malapteruridae } \\
\hline 57. Malapterurus electricus & $\mathrm{X}$ & $\mathrm{X}$ & $\mathrm{X}$ & $\mathrm{X}$ & $\mathrm{X}$ & $\mathrm{X}$ & & \\
\hline \multicolumn{9}{|l|}{ 3.3. Family: Bagridae } \\
\hline 58. Bagrus docmac & & & $\mathrm{X}$ & $\mathrm{X}$ & & & & \\
\hline \multicolumn{9}{|l|}{ 3.4. Family: Clariidae } \\
\hline 59. Clarias gariepinus & $\mathrm{X}$ & $\mathrm{X}$ & $\mathrm{X}$ & $\mathrm{X}$ & $\mathrm{X}$ & $\mathrm{X}$ & & $\mathrm{X}$ \\
\hline 60. Dinotopterus tanganicus & $\mathrm{X}$ & $\mathrm{X}$ & $\mathrm{X}$ & $\mathrm{X}$ & $\mathrm{X}$ & $\mathrm{X}$ & & \\
\hline \multicolumn{9}{|l|}{ 3.5. Family: Claroteidae } \\
\hline 61. Auchenoglanis occidentalis & & & & & $\mathrm{X}$ & $\mathrm{X}$ & & \\
\hline 62. Bathybagrus stappersii & $\mathrm{X}$ & $\mathrm{X}$ & $\mathrm{X}$ & $\mathrm{X}$ & $\mathrm{X}$ & $\mathrm{X}$ & $\mathrm{X}$ & $\mathrm{X}$ \\
\hline 63. Chrysichthys brachynema & $\mathrm{X}$ & $\mathrm{X}$ & & & & & & \\
\hline 64. Chrysichthys platycephalus & $\mathrm{X}$ & & & & $\mathrm{X}$ & & & \\
\hline 65. Chrysichthys sianenna & $\mathrm{X}$ & $\mathrm{X}$ & $\mathrm{X}$ & $\mathrm{X}$ & $\mathrm{X}$ & $\mathrm{X}$ & $\mathrm{X}$ & $\mathrm{X}$ \\
\hline 66. Chrysichthys stappersi & & & $\mathrm{X}$ & $\mathrm{X}$ & $\mathrm{X}$ & $\mathrm{X}$ & & \\
\hline 67. Lophiobagrus cyclurus & & & $\mathrm{X}$ & $\mathrm{X}$ & $\mathrm{X}$ & & & \\
\hline \multicolumn{9}{|l|}{$\begin{array}{l}\text { 4. Order: Clupeiformes } \\
\text { 4.1. Family: Clupeidae }\end{array}$} \\
\hline 68. Limnothrissa miodon & $\mathrm{X}$ & $\mathrm{X}$ & $\mathrm{X}$ & $\mathrm{X}$ & $\mathrm{X}$ & $\mathrm{X}$ & $\mathrm{X}$ & $\mathrm{X}$ \\
\hline 69. Stolothrissa Limnothrissa & & & & & $\mathrm{X}$ & $\mathrm{X}$ & & \\
\hline 70. Stolothrissa Limnothrissa juv. & $\mathrm{X}$ & $\mathrm{X}$ & $\mathrm{X}$ & $\mathrm{X}$ & & & & \\
\hline 71. Stolothrissa tanganicae & $\mathrm{X}$ & $\mathrm{X}$ & $\mathrm{X}$ & $\mathrm{X}$ & & & $\mathrm{X}$ & $\mathrm{X}$ \\
\hline \multicolumn{9}{|l|}{$\begin{array}{l}\text { 5. Order: Cypriniformes } \\
\text { 5.1. Family: Cyprinidae }\end{array}$} \\
\hline 72. Barbus paludinosus & & & & & $\mathrm{X}$ & $\mathrm{X}$ & & \\
\hline \multicolumn{9}{|l|}{$\begin{array}{l}\text { 6. Order: Synbranchiformes } \\
\text { 6.1. Family: Mastacembelidae }\end{array}$} \\
\hline 73. Aethiomastacembelus ellipsifer & $\mathrm{X}$ & $\mathrm{X}$ & $\mathrm{X}$ & $\mathrm{X}$ & $\mathrm{X}$ & $\mathrm{X}$ & & $\mathrm{X}$ \\
\hline \multicolumn{9}{|l|}{$\begin{array}{l}\text { 7. Order: Cyprinodontiformes } \\
\text { 7.1. Family: Poeciliidae }\end{array}$} \\
\hline 74. Aplocheilichthys pumilus & & & & & $\mathrm{X}$ & $\mathrm{X}$ & & \\
\hline 75. Lamprichthys tanganicanus & $\mathrm{X}$ & $\mathrm{X}$ & $\mathrm{X}$ & $\mathrm{X}$ & $\mathrm{X}$ & $\mathrm{X}$ & & \\
\hline Total: 7Orders, 12Families and 75 Species & 48 & 44 & 42 & 42 & 37 & 33 & 26 & 30 \\
\hline
\end{tabular}

Effect of change in physico-chemical attributes of water on the abundance of fish species:-

For checking the link established between the water quality and the abundance of fish species, Pearson's correlation analysis was performed. The results (Table 5) showed that the amount of fish species is negatively correlated to thirteen parameters and positively correlated to six parameters; with strong and weak relation. From the Table 5, it has been found that the increasing of fish species amount in the sampling stations is:

Significantly and strongly linked to the decreasing in value of: Total Carbon ( $\mathrm{r}=-0.998, \mathrm{p}<0.01)$, Electrical Conductivity ( $r=-0.972, \mathrm{p}<0.05)$, Total Dissolved Solids $(\mathrm{r}=-0.972, \mathrm{p}<0.05)$; Strongly linked to the decreasing in value of Total Phosphorus $(\mathrm{r}=-0.876)$,Turbidity $(\mathrm{r}=-0.759), \mathrm{pH} \quad(\mathrm{r}=-0.812)$, Dissolved Oxygen $(\mathrm{r}=-0.661)$, 
Biochemical Oxygen Demand ( $\mathrm{r}=-0.617)$ and \% of Oxygen saturation( $\mathrm{r}=-0.508)$; Weakly linked to the decreasing in value of Chemical Oxygen Demand $(\mathrm{r}=-0.368)$, Total Hardness $(\mathrm{r}=-0.114)$, Magnesium $(\mathrm{r}=-0.284)$ and Total Nitrogen $(\mathrm{r}=-0.179)$.

Significantly and strongly related to the increase in value of Iron $(r=0.908, p<0.05)$, strongly related to the increase in value of Temperature $(\mathrm{r}=0.823)$, weakly related to the increase in value of Transparency $(\mathrm{r}=0.45)$, Chlorides $(\mathrm{r}=0.185)$ and Calcium hardness $(\mathrm{r}=0.101)$.

Lastly, a very weak positive relationship is established between the fish species amount and Total Alkalinity $(\mathrm{r}=0.011)$, which shows that Total Alkalinity has almost no influence on the abundance of fish species in the sampling stations.

Table 5 :- Correlation between the fish species abundance and physico-chemical characteristics of water.

\begin{tabular}{|l|l|l|}
\hline Parameters & Correlation Coefficient (r) & Strength of relationship \\
\hline 1. Turbidity & -0.759 & Strong \\
\hline 2. Temperature & 0.823 & Strong \\
\hline 3. Transparency & 0.450 & Weak \\
\hline 4. Potential of Hydrogen & -0.812 & Strong \\
\hline 5. Total Alcalinity & 0.011 & Weak \\
\hline 6. Electrical Conductivity & $\mathbf{- 0 . 9 7 2}$ & Strong \\
\hline 7. Total Dissolved Solids & $\mathbf{- 0 . 9 7 2}$ & Strong \\
\hline 8. Chlorides & 0.185 & Weak \\
\hline 9. Total Hardness & -0.114 & Weak \\
\hline 10. Calcium hardness & 0.101 & Weak \\
\hline 11. Magnesium hardness & -0.284 & Weak \\
\hline 12. Total carbon & $\mathbf{- 0 . 9 9 8 * *}$ & Strong \\
\hline 13. Iron & $\mathbf{0 . 9 0 8}$ & Strong \\
\hline 14. Total Nitrogen & -0.179 & Weak \\
\hline 15. Total Phosphorus & -0.876 & Strong \\
\hline 16. Percent of Oxygen Saturation & -0.508 & Strong \\
\hline 17. Dissolved Oxygen & -0.661 & Strong \\
\hline 18. Chemical Oxygen Demand & -0.368 & Weak \\
\hline 19. Biochemical Oxygen Demand & -0.617 & Strong \\
\hline
\end{tabular}

** Correlation is significant at the 0.01 level (1-tailed)

* Correlation is significant at the 0.05 level (1-tailed)

Fish diversity in relation to pollution:-

Pollution status of the water at sampling stations:-

Water pollution occurs when untreated waste is thrown into water bodies. Polluted water can lead to destruction of plants and organisms living in the aquatic ecosystem and can also be harmful to peoples, plants and animals that use it. The assessment of the pollution status of the sampling stations water was focused on the analysis of the major conventional pollutant (Biochemical Oxygen Demand and Chemical Oxygen Demand) which are directly related to organic pollution. BOD is similar in function to chemical oxygen demand (COD, they both measure the amount of organic compounds in water. However, COD is less specific because it measures everything chemically oxidizable, rather than the levels of biodegradable organic matter. COD is helpful in terms of water quality by measuring the effect of an effluent on the receiving body, much like (BOD). COD range in unpolluted surface water is less than or equal to $20 \mathrm{mg} \cdot \mathrm{L}^{-1}$ (Chapman, 1997).

BOD is widely used as a surrogate of the degree of organic pollution of water (Sawyer et al, 2003); it is one of the most common measures of pollutant organic material in water and is listed as a conventional pollutant in the U.S. Clean water Act. (U.S Clean Water Act, 33 US.C.1314). BOD values indicate the extent of organic pollution in an aquatic system, which adversely affect the water quality (Jonnalagadda and Mhere, 2001). The BOD of unpolluted waters is less than $1 \mathrm{mg} . \mathrm{L}^{-1}$; moderately polluted waters have BOD content ranging from 2 to $9 \mathrm{mg} . \mathrm{L}^{-1}$ while heavily polluted waters have BOD value more than $10 \mathrm{mg}^{-\mathrm{L}^{-1}}$ (Adakole, 2000). Besides, The United Nations World Water Development (2016) states that most pristine rivers have a BOD value below $1 \mathrm{mg} . \mathrm{L}^{-1}$, Moderately polluted rivers 
have a BOD value in the range of 2 to $8 \mathrm{mg} . \mathrm{L}^{-1}$ and Rivers may be considered severely polluted when BOD values exceed 8mg.L $\mathrm{L}^{-1}$ (Connor and Richard, 2016).

In the present study, the COD value ranged from $20-67.5 \mathrm{mg} . \mathrm{L}^{-1}$ and the general mean was $34.25 \pm 20.77 \mathrm{mg} . \mathrm{L}^{-1}$ (table 3). Kajaga station appeared to be polluted by both sewage and industrial wastes as it shows high COD value with average of $67.5 \mathrm{mg} . \mathrm{L}^{-1}$. Nyamugari, Rumonge and Mvugo stations show respective mean values of $28 \mathrm{mg} . \mathrm{L}^{-1}$, 21.5mg. $\mathrm{L}^{-1}$ and $20 \mathrm{mg} . \mathrm{L}^{-1}$ (table 3). Since COD in unpolluted surface water is $\leq 20 \mathrm{mg} \cdot \mathrm{L}^{-1}$ (Chapman, 1997), all stations appeared to be polluted and the pollution stage is reflected by the BOD value. The BOD content of water ranged from 6.25 to $14 \mathrm{mg} . \mathrm{L}^{-1}$ with a general mean of $9.51 \pm 3.18 \mathrm{mg} . \mathrm{L}^{-1}$ (table 3 ). Kajaga and Nyamugari stations appeared to be polluted by sewage and industrial wastes as they have high BOD Concentration with respective averages of 14 and $10.3 \mathrm{mg} . \mathrm{L}^{-1}$. Rumonge and Mvugo stations show low mean value of 7.5 and $6.25 \mathrm{mg} . \mathrm{L}^{-1}$, respectively (table 3). According to Adakole (2000), Connor and Richard (2016), The present study revealed that waters of Mvugo and Rumonge stations were moderately polluted, while waters at Kajaga and Nyamugari sites were heavily polluted during the investigation period.

Effect of pollutants on diversity and distribution of fish species and identification of pollution indicator fish:75 fish species have been identified in all sampling stations (see Table 4) and three categories of fish species have been distinguished (Table 7), depending on their adaptation level to pollution (Table 6):

\section{Sensitive Species to pollution or Polluosensitive species:}

Species living exclusively at Mvugo and Rumonge station which are moderately polluted. In this category, 21 (or $28 \%$ ) species have been recorded and the presence of these species can be used as indicators of slightly polluted environment.

\section{Resistant Species to pollution or Polluoresistant species:}

Species exclusively inhabiting at Kajaga and Nyamugari stations which are heavily polluted. In this category, 15 (or $20 \%$ ) species have been identified and the presence of these species can serve as indicators of highly polluted environment.

Tolerant Species to pollution or Polluotolerant species:

Species adapted for living in all sampling stations, both heavily and moderately polluted. In this category, 39 (or $52 \%)$ species have been identified.

The table 6 summarizes the pollution status of the sampling stations and the acclimation level to pollution of the fish species inhabiting the respective stations while the table 7 shows the identification and distribution of fish species based on their acclimation level to pollution.

Table 6:- Pollution status of the sampling stations and Fish acclimation level to pollution.

\begin{tabular}{|l|l|l|l|l|l|l|}
\hline Plots & $\begin{array}{l}\text { Kajaga } \\
\text { (HP) }\end{array}$ & $\begin{array}{l}\text { Nyamugari } \\
\text { (HP) }\end{array}$ & $\begin{array}{l}\text { Rumonge } \\
\text { (MP) }\end{array}$ & $\begin{array}{l}\text { Mvugo } \\
\text { (MP) }\end{array}$ & $\begin{array}{l}\text { Nyamugari } \\
\text { +Kajaga (HP) }\end{array}$ & $\begin{array}{l}\text { Rumonge } \\
\text { +Mvugo(MP) }\end{array}$ \\
\hline Kajaga (HP) & Resistant & Resistant & Tolerant & Tolerant & Resistant & Tolerant \\
\hline Nyamugari (HP) & & Resistant & Tolerant & Tolerant & Resistant & Tolerant \\
\hline Rumonge (MP) & & & Sensitive & Sensitive & Tolerant & Sensitive \\
\hline Mvugo (MP) & & & & Sensitive & Tolerant & Sensitive \\
\hline $\begin{array}{l}\text { Nyamugari } \\
\text { +Kajaga (HP) }\end{array}$ & & & & & Resistant & Tolerant \\
\hline $\begin{array}{l}\text { Rumonge } \\
\text { +Mvugo (MP) }\end{array}$ & & & & & & Sensitive \\
\hline
\end{tabular}

Note:-H.P: Heavily Polluted, M.P: Moderately Polluted.

Table 7:- Identification and distribution of fish species according to their acclimation level to Pollution.

\begin{tabular}{|c|c|c|}
\hline Polluotolerant species & Polluosensitive species & Polluoresistant \\
\hline 1. Aethiomastacembelus ellipsifer & 1. Alestes macrophtalmus & 1. Aplocheilichthys pumilus \\
\hline 2. Aulonocranus dewindti & 2. Bagrus docmac & 2. Auchenoglanis occidentalis \\
\hline 3. Bathybagrus stappersii & 3. Benthochromis tricoti & 3. Barbus paludinosus \\
\hline
\end{tabular}




\begin{tabular}{|c|c|c|}
\hline 4. Bathybates fasciatus & 4. Chrysichthys brachynema & 4. Callochromis pleurospilus \\
\hline 5. Bathybates leo & 5. Cyathopharynx fulcifer & 5. Haplotaxodon microlepis \\
\hline 6. Bathybates minor & 6. Cyphotilapia frontosa & 6. Hydrocynus forskahili \\
\hline 7. Boulengerochromis micolepis & 7. Lamprologus callipterus & 7. Lates angustifrons \\
\hline 8. Callochromis macrops & 8. Lamprologus lemairii & 8. Lates microlepis \\
\hline 9. Chrysichthys platycephalus & 9. Lepidiolamprologus attenuatus & 9. Lepidiolamprologus elongatus \\
\hline 10. Chrysichthys sianenna & 10. Lobochilotes labiatus & 10. Opthalmotilapia ventralis \\
\hline 11. Chrysichthys stappersi & 11. Neolamprologus compressiceps & 11. Reganochromis calliurum \\
\hline 12. Clarias gariepinus & $\begin{array}{l}\text { 12. Neolamprologus } \\
\text { pleuromaculatus }\end{array}$ & 12. Stolothrissa Limnothrissa \\
\hline 13. Ctenochromis horei & 13. Neolamprologus tetracanthus & 13. Synodontis lacustricolus \\
\hline 14. Dinotopterus tanganicus & 14. Perissodus microlepis & 14. Triglachromis otostigma \\
\hline 15. Gnathochromis pfefferi & 15. Simochromis marginatus & 15. Xenotilapia longispinis burtoni \\
\hline 16. Haplochromis burtoni & 16. Stolothrissa Limnothrissa juv. & \\
\hline 17. Hemibates stenosoma & 17. Synodontis multipuctatus & \\
\hline 18. Hydrocynus goliath & 18. Telmatochromis temporalis & \\
\hline 19. Lamprichthys tanganicanus & 19. Trematocara marginatum & \\
\hline 20. Lates mariae & 20. Tropheus brichardi & \\
\hline $\begin{array}{l}\text { 21. Lepidiolamprologus } \\
\text { cunningtoni }\end{array}$ & 21. Xenotilapia boulengeri & \\
\hline 22. Limnochromis auritus & & \\
\hline 23. Limnothrissa miodon & & \\
\hline 24. Limnotilapia dardennei & & \\
\hline 25. Lophiobagrus cyclurus & & \\
\hline 26. Luciolates microlepis & & \\
\hline 27. Luciolates stappersii juv. & & \\
\hline 28. Luciolates stappersi & & \\
\hline 29. Malapterurus electricus & & \\
\hline 30. Neolamprologus brevis & & \\
\hline 31. Neolamprologus Calvus & & \\
\hline 32. Oreochromis niloticus & & \\
\hline 33. Oreochromis tanganicae & & \\
\hline 34. Stolothrissa tanganicae & & \\
\hline 35. Trematocara variabile & & \\
\hline 36. Tylochromis polylepis & & \\
\hline 37. Xenotilapia flavipinnis & & \\
\hline 38. Xenotilapia sima & & \\
\hline 39. Xenotilapia burtoni & & \\
\hline
\end{tabular}

Similarity between fish species richness of sampling stations:-

The similarity between fish species recorded in the sampling stations was determined using similarity indices. The most used indices are similarity coefficients of Jaccard (1908) and Sorensen (1948). These indices are used to compare objects on the basis of the presence-absence of species and are so very simple measures of beta biodiversity, ranging from 0 (when there are no common species between two communities) to 1 when the same species exist in both communities). A smaller index indicates less similarity in species composition between different habitats (Condit et al., 2002; Nshimba, 2008). The table 8 shows Similarity Index between the fish species composition of sampling stations, which is calculated using Jaccard and Sorensen's Method.

From the table 8, it is obvious that Jaccard and Sorensen indices give different coefficient values for the same pair of distinct sampling stations but they reflect both, the same information. Indeed, Rumonge $\mathrm{x}$ Mvugo pair occupies the first position with a high similarity coefficient of 0.67 and 0.5 for Sorenson and Jaccard's index respectively. This 
means that many fish species are common or shared between Mvugo and Rumonge stations which are moderately polluted and shows that these two stations have almost the same environmental conditions or characteristics.

Rumonge x Kajaga, Rumonge x Nyamugari and Mvugo x kajaga pairs occupy respectively the second, third and fourth rank with respective Sorensen's similarity coefficients of $0.58,0.55$ and 0.53 . The respective Jaccard Indices are $0.41,0.38$ and 0.36 . These three indices are so close in value and are close to the average (for Sorensen's index) compared to the extreme values (ranging from 0 to 1 ). This shows the presence of tolerant fish species to the environmental conditions prevailing in all sampling stations, which are moderately and heavily polluted. The similarity between fish species composition of Nyamugari x Mvugo and Nyamugari x Kajaga site pairs is very low. It occupies the fifth and sixth position which is the last with respective Sorensen's similarity indices of 0.47 and 0.37 , the respective Jaccard's indices are 0.31 and 0.23 . This shows that the environmental conditions prevailing in Kajaga, Nyamugari and Mvugo stations are very different and apart from the status pollution of sampling sites, there are some else factors that strongly influence the similarity or disimilarity of the specific composition of sampling sites such as the presence or absence of sufficient planktonic nutrients.

Table 8:- Similarity coefficient between fish species composition of sampling stations.

\begin{tabular}{|c|c|c|c|c|c|}
\hline Plots & Kajaga & Nyamugari & Rumonge & Mvugo & Similarity Index \\
\hline Kajaga & 1 & 0.23 & 0.41 & 0.36 & \multirow{4}{*}{$\begin{array}{l}\text { Jaccard's } \\
\text { Index }\end{array}$} \\
\hline Nyamugari & & 1 & 0.38 & 0.31 & \\
\hline Rumonge & & & $\mathbf{1}$ & 0.50 & \\
\hline Mvugo & & & & 1 & \\
\hline Kajaga & 1 & 0.37 & 0.58 & 0.53 & \multirow{4}{*}{$\begin{array}{l}\text { Sorensen's } \\
\text { Index }\end{array}$} \\
\hline Nyamugari & & 1 & 0.55 & 0.47 & \\
\hline Rumonge & & & 1 & 0.67 & \\
\hline Mvugo & & & & 1 & \\
\hline
\end{tabular}

Effect of sampling sites on the abundance of fish species:-

Tukey's Honestly Significant Difference test (Tukey's HSD) and One-way Analysis of Variance (ANOVA-1) both at the 5\% level were performed respectively to make the averages comparison and to assess the effect of the sampling sites on the abundance of fish species. The results of one-way Analysis of variance (ANOVA-I) (Table 9) indicated that the influence of the study stations on the abundance of fish species is highly significant $(p=0.007)$. It means that the variation of fish species in number depends on the environmental conditions. The differences among pairwise averages number of fish species from the sampling stations are shown by Tukey's HSD multiple comparison test in the table 10 and it has been reflected that the mean difference of fish species amount between stations is significant $(\mathrm{p}<0.05)$ for Kajaga and Rumonge sites $(\mathrm{p}=0.036)$, Nyamugari and Rumonge sites $(\mathrm{p}=0.006)$, Nyamugari and Mvugo sites ( $\mathrm{p}=0.016)$. The comparison of the average number of fish species using Tukey's HSD at the 5\% level classifies the 4sampling stations into 3homogeneous subsets of averages A, B and C (Table 11). Indeed, the averages belonging to the same homogeneous subset are not significantly different (e.g: Nyamugari and Kajaga or Kajaga and Mvugo or Rumonge and Mvugo stations) whereas the averages belonging to different homogeneous subsets are significantly different because the subsets A, B and C are different.

Table 9:- ANOVA-I showing the effect of sampling sites on fish species number.

\begin{tabular}{|l|l|l|l|l|l|l|}
\hline Variable & Variation Source & Sum of Squares & Freedom Degree & Mean Square & F Test & p-value \\
\hline \multirow{2}{*}{$\begin{array}{l}\text { Fish species } \\
\text { amount }\end{array}$} & between study sites & 377.5 & 3 & 125.833 & $20.972^{* *}$ & 0.007 \\
\cline { 2 - 8 } & within study sites & 24 & 4 & 6 & & \\
\cline { 2 - 8 } & Total Variance & 401.5 & 7 & & & \\
\hline
\end{tabular}

Table 10:- Tukey's HSD multiple comparison test for the differences of pairwise averages amount of fish species among the sampling stations.

\begin{tabular}{|l|l|l|l|l|}
\hline Dependent Variable & Sampling stations (I) & Sampling stations (J) & Mean Difference (I-J) & p-value \\
\hline \multirow{3}{*}{ Fish species amount } & \multirow{3}{*}{ Kajaga } & Nyamugari & 7 & 0.142 \\
\cline { 3 - 5 } & & Rumonge & $\mathbf{- 1 1}$ & $\mathbf{0 . 0 3 6}$ \\
\cline { 2 - 5 } & Mvugo & -7 & 0.142 \\
\cline { 2 - 5 } & \multirow{2}{*}{ Nyamugari } & Rumonge & $\mathbf{- 1 8}$ & $\mathbf{0 . 0 0 6}$ \\
\cline { 3 - 5 } & & Mvugo & $\mathbf{- 1 4}$ & $\mathbf{0 . 0 1 6}$ \\
\hline
\end{tabular}


Rumonge

Mvugo

4

0.455

Table 11:- Tukey's HSD showing Homogeneous subsets of averages at sampling Stations.

\begin{tabular}{|c|l|l|l|l|l|}
\hline \multirow{2}{*}{$\begin{array}{c}\text { Dependent } \\
\text { Variable }\end{array}$} & \multicolumn{2}{c|}{$\begin{array}{c}\text { Factor } \\
\text { (Sampling Stations) }\end{array}$} & \multicolumn{2}{c|}{$\begin{array}{c}\text { Means for groups in homogeneous subsets } \\
\text { for Alpha=0.05 }\end{array}$} & \multirow{2}{*}{ Homogeneous Subsets } \\
\cline { 3 - 6 } & & $1(\mathrm{~A})$ & $2(\mathrm{~B})$ & $3(\mathrm{C})$ & \\
\hline \multirow{3}{*}{$\begin{array}{c}\text { Fish species } \\
\text { amount }\end{array}$} & Nyamugari & 28 & & & $\mathrm{~A}$ \\
\cline { 2 - 6 } & Kajaga & 35 & 35 & & $\mathrm{BC}$ \\
\cline { 2 - 6 } & Mvugo & & 42 & 42 & $\mathrm{C}$ \\
\cline { 2 - 5 } & Rumonge & & 46 & \\
\hline
\end{tabular}

\section{Conflict Of Interest:-}

The authors declare that they have no conflict of interest to report with respect to the research, authorship and publication of this article.

\section{Acknowledgement:-}

The authors would like to express the sincere gratitude to the Indian Council for Cultural relations (ICCR) of the Indian government and to the ministry of higher education and scientific research of the Burundian government for providing the financial support.

The authors extend their thanks to Prof. Gaspard Ntakimazi, professor of the University of Burundi for his guidance and encouragement during the study and to Mr. Bernard Nzungu for his assistance during laboratory analysis and field data collection.

Lastly, the local people residing nearby Lake Tanganyika, especially the fishermen are also thankfully acknowledged for their co-operation and help during the time of field data collection.

\section{Conclusion:-}

The specific objective of the present investigation is an attempt to assess the current pollution aspect of the sampling sites and the spatial variations of physico-chemical parameters (pollutants) and their influences on the abundance and spatial distribution of fish species.

The results obtained regarding the taxonomy and abundance of fish species showed a total of 75 fish species belonging to 12 families and 7 orders from all selected sampling sites and the relative diversity index of families has indicated that Rumonge site holds first position with an average of 46 species distributed into 9 families, Mvugo site in the second position with 42 species distributed into 11 families, Kajaga site in third position with an average of 35 species distributed into 11 families and Nyamugari site appeared as the poorest with an average of 28 species distributed into 6 families. Besides, the similarity index between sampling stations proved that Rumonge and Mvugo pair have a high similarity coefficient (Sorensen index=0.67) which indicated that many fish species are common or shared between Mvugo and Rumonge stations and the environmental conditions prevailing in these two stations are almost the same.

Regarding the pollution status of the sampling locations and the impact of water quality on the abundance and fish diversity, it has been proved that Kajaga and Nyamugari stations were heavily polluted while Rumonge and Mvugo Stations were moderately polluted. In this regards, three categories of fish species have been distinguished, based on their adaptation level to pollution like (i) polluosensitive species, (ii) polluoresistant species and (iii) polluotolerant species. On the other hand, Karl Pearson's correlation coefficient calculated between physico-chemical parameters values and the number of fish species showed strong positive correlation (for Temperature and Iron) and negative correlation (for Turbidity, Potential of Hydrogen, Electrical Conductivity, Total Dissolved Solids, Total carbon, Total Phosphorus, \% of Oxygen saturation, Dissolved Oxygen and Biochemical Oxygen Demand) which revealed that physico-chemical parameters have a high influence on the increase and the decrease of fish species amount in the study environment and at the same time, one-way Analysis of variance (ANOVA-I) and Tukey's Honestly Significant Difference test (Tukey's HSD) have showed that the influence of the study stations on the abundance of fish species is highly significant $(\mathrm{P}=0.007)$. 


\section{Bibliography:-}

1. Adakole, JA. (2000). The effects of domestic, agriculture and industrial effluents on the water quality and biota of Bindare stream, Zaria. Nigeria, PhD Thesis, Department of Biological Sciences, Ahmadu Bello University, Zaria, Nigeria, 256p.

2. Allen, GR.(1991). Field Guide to the Freshwater Fishes of New Guinea. Publication No. 9 of the Christensen Research Institute, Madang, New Guinea.

3. Allen, GR.; Hortle, KG.; Renyaan SJ. (2000). Freshwater fishes of the Timika Region, New Guinea. P.T. Freeport Indonesian Company, Timaka, Indonesia.

4. APHA.(2005). Standard methods for the examination of water and waste water. American Public Health Association 21st Edn., Washington, D. C.

5. Balance, JR.(1996). Water quality monitoring, a practical guide to the design and implementation of freshwater quality studies and monitoring programmes. UNEP and WHO,Geneva.

6. Boon, J.; Calow, P.; Petts GE.(1992). River conservation and management.Wiley, Chichester.

7. Chapman. (1997). Water Quality Assessments: A guide to the use of biota, sediments and water in environmental monitoring; London, E \& FN SPON.

8. Chovance, A.; Hoffer, R.; Schiemer, F. (2003). Fish as bioindicators. In: Market BA, Breure AM, Zechmeiser HG (eds) Bioindicatos and biomonitors, pp 639-675

9. Clair, N.; Sawyer; Perry, L.; McCarty; Gene, F.; Parkin. (2003). Chemistry for Environmental Engineering and Science (5th ed.). New York: McGraw-Hill. ISBN 0-07-248066-1.

10. Condit, R.; Pitman, N.; Leigh, E.; Chave, J.;Terborgh, J.; Foster, R.; Nunez, V.; Aguilar, S.; Vaencia, R.; Villa, G.; HC, M.L.; Losos, E.; Hubbell, S.(2002). Beta-diversity in tropical forest trees. Science.295: 666-669.

11. Connor, Richard. (2016). The United Nations World Water Development Report 2016: Water and Jobs, chapter 2: The Global Perspective on Water. Paris: UNESCO. p.26. ISBN 978-92-3-100155-0.

12. Cuizhang, Fu.; Wu, J.; Chen, J.; Wu, Q.; Lei, G. (2003). Fresh water fish biodiversity in the Yangtze River basin of China: patterns, threats and conservation. Biodivers. Conserv. 12:1649-1685.

13. Darwall, WRT.; Vie, JC.(2005). Identifying important sites for conservation of freshwater biodiversity: extending the species based approach. Fish Manag. Ecol. 12:287-293

14. Dawson, TP.; Berry, PM.; Kampa, E. (2003). Climate change impacts on freshwater wetland habitat. J Nat Conserv. 11:25-30

15. Dutta Munshi , JS.; Shrivastava, MP.(1988). Natural history of fishes and systematics of freshwater fishes in India. Narendra Publishing Co. Delhi, India.

16. Fink, SV. Fink, WL. (1981). Interrelationships of the Ostariphysan Fishes (Teleostei). Journal of Linnean Society of Zoology.724: 297-353.

17. Gibbs, JP. (2000). Wetland loss and biodiversity conservation.Conserv Biol.14(1):314-317

18. Jaccard, P. (1908). Nouvelles recherches sur la distribution florale. Bull. Soc. Vaud. Sci. Nat. 44:223-270.

19. Jayaram, KC. (1999). The Freshwater Fishes of the Indian Region. Narendra Publishing House, Delhi.

20. Joshi, DK. (2014). Marine pollution and its effect to the bio-diversity. Int J Dev Res.4:289-293.

21. Kang, B.; He, D.; Perrett, L.; Wang, H.; Hu, W.; Deng, W.; Wu, Y. (2009). Fish and fisheries in the Upper Mekong: current assessment of the fish community, threats and conservation. Rev Fish Biol Fish.19:465-480.

22. Khanna, DR.; Ishaq, F. (2013). Impact of water quality attributes and comparative study of icthyofaunal diversity of Asan Lake and River Asan. J. Appl. Nat Sci. 5(1):200-206

23. Laffaille, P.; Acou, A. ; Guillouet, J. ; Legult, A. (2005). Temporal change in European eel, Anguilla anguilla, stock in a small catchment after installation of fish passes. Fish Manag Ecol.12:123-129

24. Lauder, GV.; LIEM, FL.(1983). The evolution and interrelationships of Actinopterygian fishes. Bull. Mus. Comp. Zool.150: 95-197.

25. Leveque, C.; Balian, EV.; Martens, K. (2005). An assessment of animal species diversity in continental waters. Hydrobiologia.542:32-67.

26. Lima-Junior,SE.; Cardone, IB.; Goitein, R. (2006). Fish assemblage structure and aquatic pollution in a Brazilian stream: some limitations of diversity indices and models for environmental impact studies. Ecol Freshw Fish.15 (3):284-290.

27. Marquet,G.; Keith, P.; Vigneux, E. (2003). Atlas des poissons et des crustacés d'eau douce de Nouvelle Calédonie. Patrimoines Naturals, Paris.

28. Mas-Marti, E.; Garcia-Berthou, E.; Sabater, S.; Tomanova, S.; Monoz, I. (2010). Comparing fish assemblages and trophic ecology of permanent and intermittent researches in a Mediterranean stream. Hydrobiologia. doi:10.1007/s10750-010-0292-x. 
29. Mohite, SA.; Samant, JS. (2013). Impact of environmental change on fish and fisheries in Warna River Basin, Western Ghats, India. Int Res J Environ Sci 2(6):61-70

30. Nelson, JS. (1994). Fishes of the world. 3. ed., John Wiley \& Sons, New York, 600p.

31. Noukeu, NA.; Gouado, I.; Priso, RJ.; Ndongo, D.; Taffouo, VD.; Dibong, SD.; Ekodeck, GE. (2016). Characterization of effluent from food processing industries and stillage treatment trial with Eichhorniacrassipes(Mart.) and Panicum maximum (Jacq.). Water Resources and Industry, 16: 118.https://doi.org/10.1016/j.wri.2016.07.001

32. Nshimba, H.(2008). Etude floristique, écologique et phytosociologique des forêts inondées de l'île Mbiye à Kisangani. Thèse de doctorat inédite, ULB, Bruxelles, 389p.

33. Ntakimazi,G.; Nzigidahera,B.; Fofo,A. (2007). Poissons Du Burundi, Lexique des noms kirundi, 53p.,available online :http://bi.chm-cbd.net/chm-burundais/pfinstitut/direction-des-eaux-de-la-peche-et-de-laquaculture/projets-et-realisation/documents-de-politiques-et-de-strategies/poisson-du-burundi-lexique-desnoms-en-kirundi.

34. Paugy, D.; Lévêque, C.; Teugels, GG. (2003). Poissons d'eaux douces et saumâtres de l'Afrique de l'Ouest, édition complète. Tome I \& II. Edition IRD-MNHN-MRAC, Paris-Turvuren. 457 + 815P.

35. Pompeu, PS.; Alves, CBM. (2003). Local fish extinction in a small tropical lake in Brazil. Neotropical Ichthyol.1(2):133-135.

36. Pompeu, PS.; Alves, CBM. (2005). The effects of urbanization on biodiversity and water quality in the Rio das Velhas Basin, Brazil. Am Fish Soc Sym. 47:11-22.

37. Ricciardi, A.; Rasmussen, JB. (1999). Extinction rates of North American freshwater fauna. Conserv Biol.13:1220-1222.

38. Roxane, T.; Reinhard, P. (2015). Limnological characteristics of 56 southern Quebec lakes in relation to the trophic status. Journal of Water Sciences.28 (2): 139-162.

39. Sarkar, UK.; Pathak, AK.; Lakra, WS. (2008). Conservation of freshwater fish resources of India: new approaches, assessment and challenges. Biodivers Conserv.17:2495-2511.

40. Sharma, A.; Sharma, RC. ; Anthwal, A. (2007). Monitoring phytoplankton diversity in the hill stream Chandrabhaga in Garhwal Himalayas. Life Sci. J. 4, 80-84.

41. Shukla, P.; Singh, A. (2013). Distribution and diversity of freshwater fishes in Aami River, Gorakhpur, India. Adv Biol Res. 7(2):26-31.

42. Sorensen, TA.(1948). Method of establishing groups of equal amplitude in plant sociology based on similarity of species content. K. Dans ka Videnskab Selsk. Biol. Skr. 5(4):1-34.

43. Szollosi-Nagy. (2004). In Proceedings of the United Nations seminar,25-26 November 2004, Delft, Netherlands.

44. Talwar, PK.; Jhingran, A. (1991). Inland fishes of India and adjacent countries, 2 volumes. Oxford and IBH Publishing Co. Pvt. Ltd., New Delhi, xix? 1158 pp.

45. Trivedi, RK. ; Goel, PK. (1986). Chemical and biological methods for water pollution studies, Environmental Publications, Kard(India). Ress Company, Smith, Ronald G.M, Press Company, New York.

46. United States, Clean Water Act sec. 304(a) (4). Title 33 of the United States Code outlines the role of navigable waters in the United States Code. 1314(a).

47. Venkatesharaju, K.; Ravikumar, P.; Somashekar, RK.; Prakash, KL. (2010). Physico-chemical and Bacteriological investigation on the river Cauvery of Kollegal Stretch in Karnataka, Journal of Science Engineering and Technology. 6 (1): 50-59.

48. Vishwanath,W.(2002). Fishes of North East India, a field guide to species Identification. Manipur University NATP Publication. 198p.

49. Watson, RE. (1992). A provisional review of the genus Stenogobius with descriptions of a new subgenus and thirteen new species (Pisces:Teleostei:Gobiidae). Records of the Western Australian Museum.15: 571-654.

50. Watson, SB.; John, L. (2003). Overview on drinking water quality and sustainability. Water Qual. Res. Jour. Canada.38 (1): 3 - 13.

51. Wetzel, RG.(1983).Limnology Philadelphia,Saunders College Publishing, 858p.

52. Wetzel, RG. (2001). Limnology Lake and river ecosystems. San Diego, Academic Press, 3rd edition, 1006p. 